\title{
Alpine tourism as an economic development factor. A market perspective
}

\section{Giuseppe Tardivo}

Department of Management, University of Turin, Turin, Italy

\section{Email address:}

giuseppe.tardivo@unito.it

\section{To cite this article:}

Giuseppe Tardivo. Alpine Tourism as an Economic Development Factor. A Market Perspective. Journal of Investment and Management. Special Issue: Attractiveness and Governance of Tourist Destinations. Vol. 4, No. 1-1, 2015, pp.10-16.

doi: $10.11648 /$ j.jim.s.2015040101.12

\begin{abstract}
Tourism trends and policies is becoming an international reference and benchmark on how effectively countries are supporting competitiveness, innovation and growth, and shed light on policies and practices associated with this. Despite the topic of attractiveness of tourist destinations is at the center of the international economic debate, there are still many areas showing important gap among potentials and performances and in most cases literature doesn't offer a suitable measure and strategic solutions for this problem. From a destination-based tourism model, the transition has been made to a model driven by motivation and the search of experience. The forces driving the change are: internet, low costs, tour operators, OTAs and the new demand for experiences from tourists, which have changed the rules of the game and, most importantly, altered the balance between supply and demand. The paper has three research goals. Firstly, a driven-based analysis will be presented, aimed at identifying the factors which condition and/or support the sector, briefly touching a legislation, governance, funding and infrastructure and cultural heritage. Subsequently the paper will focus some deficiencies of the tourist system in Italy, still organized according to an endogenous vision of the sector's development, and based on a model turned to a production perspective in which the offer is placed at the center of the system, with no added value and limited activity in term of retails, marketing and innovation and low level of professional competence. Finally the research will aim to propose a change of the tourism policy in Italy. As well as a reorganization of offer in a more innovative and experienced-based key, to be more competitive Italy needs the role of local government to be extensively reviewed: local administrations will have to take leadership of the destinations, bringing a strategic vision to the territory and becoming the main actor in conceiving and designing the offer of tourism.
\end{abstract}

Keywords: Destination Management, Governance, Tourism Development, Tourism Cultural Heritage

\section{Introduction}

Tourism is associated with travel and consumption which is in turn generally linked to possession of such resources as leisure time and disposable wealth. It is a large industry and the subject of considerable study and interest.

"In the OECD area, domestic tourism consumption represents a very significant share of the total tourism economy, averaging $61 \%$, and above $80 \%$ for Chile, Germany, Japan, Mexico, the United Kingdom an the United States. Evidence shows that domestic tourism consumption, as a proportion of internal tourism consumption, is much higher for OECD member economies, than for non-member $(47.5 \%)$. It is noticeable that many countries are placing greater emphasis on, and taking additional supportive measures to encourage domestic tourism, recognizing that domestic tourism is as capable of supporting employment and adding local value as international tourism. Many of the emerging tourism destination countries are enjoying significant growth in arrivals, and outperforming OECD and global average for GDP and employment. While still accounting for a relatively small proportion of global international arrivals, the potential impact of tourism on these economies is clear. Countries such as Argentina, Brazil, Egypt, India, Indonesia, and South Africa represent a significant potential as sources of growth for traditional tourism destinations. Against this background, it is unsurprising that governments increasingly regard tourism as an area for which the development and application of 
supportive policies are important, and an area where the potential benefit of government intervention should not be overlooked. In 2012, the dominant concern of those responsible for the development of tourism remains the international financial and economic crisis and the relatively poor outlook for many national economies. Some countries have also had to deal with the consequences of major natural disaster - such as the tsunami in Japan and the earthquake in New Zealand - or political upheaval such as that experienced in a number of Middle Eastern and Mediterranean countries." [1]

Italian touristic model is still based on the one of the ' 80 -'90ies, characterized by the scarcity of competitors and the abundance of demand. In this case, supply dictates conditions and the client must consume a standardized and rigid product. Italian touristic system is not too flexible and it has evident weaknesses when adapting to demand trends.

"This is primarily a service industry (as contrasted to manufacturing) and generally employs a large number of people on relatively low wages (as opposed to banking and financial services). The industry according to the ECORYS Report confronts a number of what they describe as megatrends" [2]:

Tourism Megatrends

1: Globalisation

2: Demographic change

3: Access to information

4: Experience economy

5: Customisation

6: Sustainability

7: Health and wellness

This model refers to a post-fordist and industrial logic. In most cases, the Italian touristic business is characterized by its extreme simplicity: operators use and exploit resources and attractions, with no transformation and no added value in creating the supply, with poor structural investments and very poor commercial and marketing activities.

Joseph Ejarque, President and Managing Director of Four Tourism S.r.l. states: "In the Italian business model, the commercial aspect and the relation with the market are not developed. A strong relationship with clients is inexistent or poorly developed. The supply is commercialized and put into the market by third parties (i.e. tour operators and online travel agencies - OTA). Italian tourism has a passive attitude and an inadequate commercial capacity, which compromises the operative efficiency and causes a strong reduction in benefits. The national touristic supply consequently becomes excessively standardized, and loses attractiveness in comparison with the one of competitors. It is penalized by a very expensive cost structure deriving from poor innovation and the insufficient use of new product management technologies.

The change tourism is undergoing is so strong that inevitably all management and governance models for tourism policies still applied in Italy are totally obsolete and inadequate to real market demand" [3].

This change in tourism paradigm has happened because of the irruption of two factors: low cost models and the Internet as instruments to inform and advert-commercialize. Both elements have brought about a change in demand. At first, annual holydays were the most important economic investment in a year (apart from buying a house or a car) and were taken in a one and only break. Then tourism started being considered as a "commodity".

Commoditization of tourism changed. The annual and expensive demand became a cheaper demand for shorter trips and cost attention started being stronger (short-break tourism): demand for a new kind of tourism, with a huge growth in the number of journeys. Easier access to information greatly favoured and accelerated this process of change, especially thanks to the Internet. More destination supplies, shorter time to reach final destinations and strong low-cost models provoked the rise of new short and medium-range destinations perfect for short-break tourism. Together with new destinations, new forms of tourism were born, linked to specific interests that caused a further evolution, i.e. the segmentation of demand.

Post-modern society has favoured the birth of new values in tourists: hedonism, ethical value research, mental and physical health. All this gave rise to a new model of motivational touristic consumption and the search for added value deriving from touristic experience [4].

The new model of touristic demand is based on personalization (instead of standardization), on activity and experience (instead of passivity), on intensity and on multi-products (instead of simplicity). From destination tourism to tourism for destination products: present motivations for choosing a destination are not very different from those of a dozen years ago. The need for innovation and change has destroyed loyalty and the loyalty management of tourists for a specific destination. The rise of new products, the interest in health, sport and hobby has accelerated the maturity of destinations and these have not been able to renovate their attractiveness (cities full of art and history).

The new paradigm of tourism responds to a "liquid" society in continuous transformation, in which tourism is considered a direct extension of everyday life, a temporary and necessary parenthesis, with a great intrinsic value for the self. We then witness the birth and the progressive consolidation of "theme tourism". What really counts here is not just the destination but also the kind of activity and motivations that mark each destination [5].

Destinations become competitors not because of their brand but as product containers. In sum, and without entering into, analysing and justifying the totality of factors that have an impact on Italian competitiveness (i.e. the dimension of tourism businesses, their low capability to innovate and all high operational and managerial costs) we can state that Italian touristic offer is still too "solid" compared with a more and more "liquid" market.

Tourists today are profoundly diverse from the one on which the Italian touristic model was elaborated. Tourists are innovators. They are informed, unfaithful, deceived, impatient and "intoxicated", which means bombed by a lot of information daily. Especially, they are mature and evolved 
tourists, and often they have more expectations that touristic destinations manage to fulfil.

Tourists today must not be defined as Prosumers, but as Adprosumers: thanks to the Internet, they produce both the product they wish to consume and its relevant information. Available instruments are numerous: they can publicize, inform, share and comment. There emerges a huge lack of tourism supply: its inadequate presence in the Internet".

In some Italian regions there are few integrated strategic and touristic management marketing plans. In most cases no accurate touristic strategy exists, no functional organization to be able to design and manage a regional, competitive, attractive, efficient and effective touristic system.

Many areas have a strong touristic vocation and a high potentiality is present in many others but they never managed to emerge because of an absence of strategy, direction and management skills. The potential of land resources could activate touristic theme-based projects and offers that could be easily positioned on the market, but they don't manage to do it because of a lack of strategy in the construction of product-destination.

\section{Possible Improvement Paths}

The Italian touristic system must analyse two aspects. The first one is destination management to which administrations can contribute with a strategic vision of the territorial system. The second one is the organization and creation of product destinations - structuring and managing the area, taking on the strategic leadership of tourism in destinations, both at a local and at a global level [6]

Dealing with tourism from the inside of an administration today, at any level, forces people to keep updated and to be fully conscious about tourism. The time when the administrative approach and resolutions were dominating this sector is over.

"It is necessary to know the realty of this market, to understand the dynamics of this sector and of its demand and supply. One must know that the tourism of an area must be able to answer to demand trends and not to a vision and a logistic or flag-waving will. Tourism must not be taken for granted anymore but it must be organized, structured and managed.

Administrations should take on the responsibility to look in the distance and decide the leading path towards the development of the touristic system based on destinations, both at a local level and at a regional one.

"These trends present challenges for tourism and also raise questions over the relationship between sectors in the tourism industry. They key role of the public sector in tourism is well established in terms of such factors as infrastructure (roads, health care, sanitation and security for example).

The prominence of the EU as a tourism destination is implicitly linked to the fact that EU countries are considered to be safe destinations and to possess good infrastructure. The concerns following incidents of terrorism are demonstrative of this.
Conventionally the economic value chain involved in tourism has involved the private sector as provider of travel, accommodation and the majority of aspects of the value chain other than that furnished by the public sector infrastructure as described above.

The service aspects of tourism carry the implication of a purchaser and a market place. The value attached to the purchase in conventional terms is seen in economic terms namely that usual laws of supply and demand operate and that factors such as price, economies of scale in production and a focus upon competitive forces are the determinants of outcome" [2].

It is necessary to abandon political-administrative dynamics and accept the vision that tourism is a market with its economic attraction and the tourist is the client of an area.

Renewing the supply, creating new touristic-territorial products, reorganizing tourism area management, giving more incentives to innovation, ameliorating promotions, realizing advert-commercialization and especially managing the governance of this system in the best possible way, are the fundamental objectives for a sustainable touristic policy.

Two basic strategic concepts may be useful as a possible development process. Tourism today moves because of motivations and not because of destinations. The evolution of clients in the last few years has been much faster than the one of destinations. Touristic demand has changed from a model of non-migratory and passive tourism to an active tourism made of emotions and experiences.

The growth of activities at the heart of the system (promotion, investment, innovation, etc....) and the newness and differentiation of the product will have to co-habit with differentiated products and destinations. Obviously market relations will have to be managed in a multichannel optic, directly or indirectly".

The improvement of touristic governance should have an impact on aspects such as strategic promotional coordination, re-engineering of destinations and of mature touristic products, together with an ameliorated flux management and the organization of the system, supporting the creation of networks among operators [7].

Innovation and intelligence development techniques in the market can help design new product and re-engineered destinations and mature products. Distribution, entering in new markets and market segments with adequate advert-commercialization techniques could certainly help the evolution of Italian Regions, from simple destinations in pain to new and successful realities on the new market.

From this point of view, tourism can have a fundamental role for a socio-economical area that is particularly dear to the economy of Piedmont and Cuneo: alpine tourism.

\section{Alpine Tourism}

Alpine tourism, magic words that transform an unknown water source dear to a shepherd and his herd in a famous thermal source whose water is sold at the price of wine, is now apparently oriented to satisfy a seasonal kind of demand. 
Let's remember the case of Limone (2012): 600 beds available in hotels; 28.000 beds in holyday homes (90.000 in the whole mountain area of Cuneo); 20.000 daily occupancies in the two central weeks of August and Christmas.

During the last ten years, tourism has become an amazing tool to develop and valorise alpine economy [8] (fig.1 and tab.1).

From the high valleys, rich in trees and woods, vast meadows, natural lakes and itineraries for excursions, to the

foothill area, with its chestnut woods, thermal venues, mineral water springs, fantastic natural attractions (i.e. Bossea grottoes), the soft hills of Langhe and Astigiano, Piedmont can offer the most varied possibilities of attraction.
The explosion of agro-tourism and "equipped parks", thanks to an ever-growing demand also proves this [9].

In most cases we witness a divarication of structures. On one side, one finds great touristic locations, where big investors build huge home-buildings (Limone Piemonte is one of the many examples. Let's cite Bardonecchia too, where hotel available beds are only $6 \%$ of the total). On the other side, there are local traditional housing facilities offered by the local people. The basis of tourism - the Alps, a "wonderful landscape" or a cultural and incoming area - is not then an acquired "certainty", but it only develops in the context of the industrial revolution as a clear re-evaluation of the relation between humans and nature.

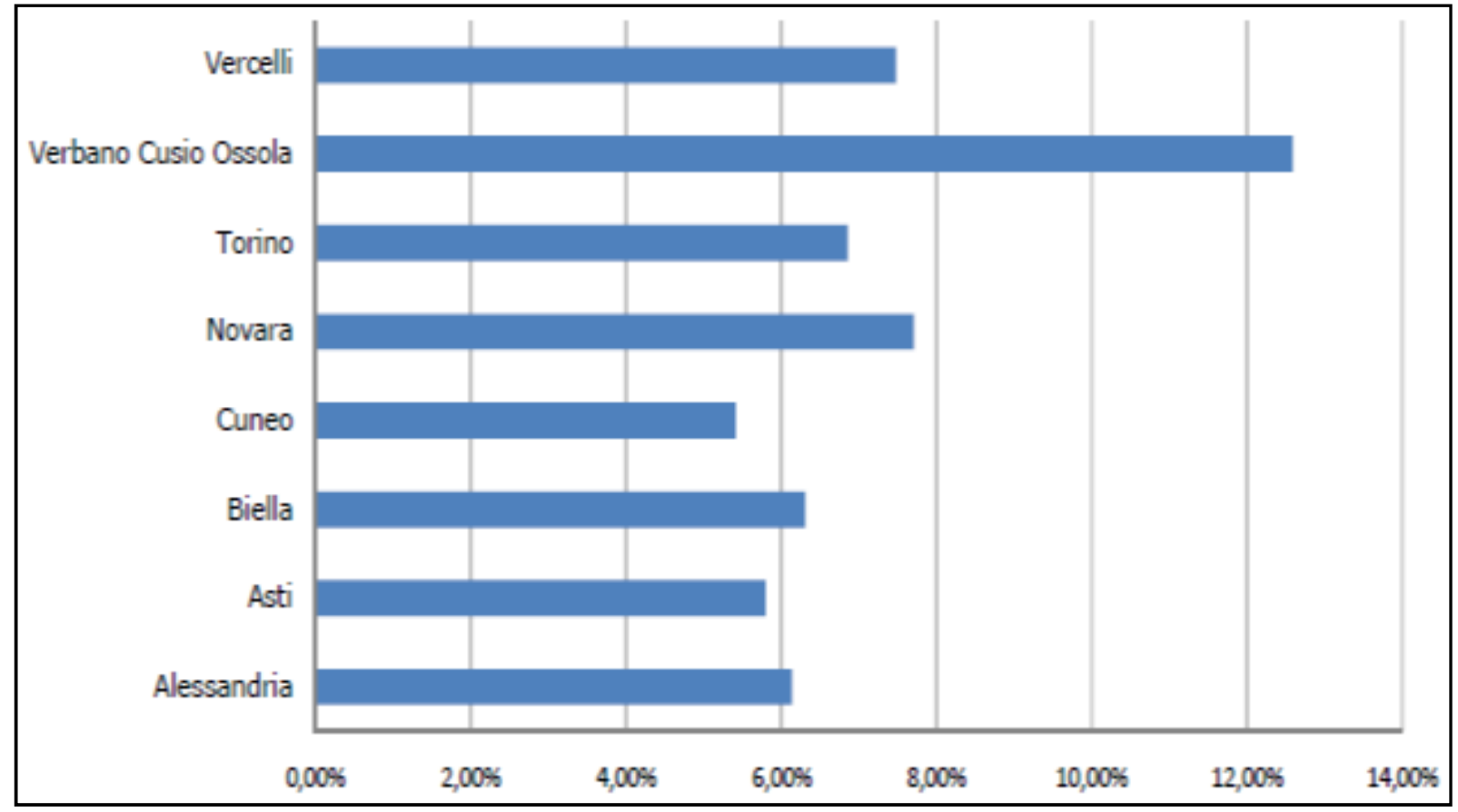

Source: Camera di Commercio di Cuneo ( 2014)

Figure 1. Piedmont: touristic companies on total companies (\%)

Thousands of small craftsmanship businesses are directly linked to tourism. These are $36,6 \%$ of total local enterprises with high quality products.

In some zones, in Piedmont, (i.e. the "Via Lattea" tourist resort) there are lots of small artisanal businesses and they are very well integrated with tourism.

How can one valorise alpine tourism?

We mentioned before that the main motive for touristic travels is and will always be, for alpine areas, the landscape and the charm of mountain areas.

The second exploitable potential is wine and food attractions.

Tourism means education, culture, and respect of the landscape and of art. It also means an especially important source of wealth, which compensates in the near future many humiliating frustrations [10].

Critical situations exist. Mountains in Piedmont are also a fragile area with a certain level of irregularly distributed criticalities and risks.
First of all, the ample presence of "Les Favorites Areas", presented as a negative process going through sequential phases of demographic and economic connotation, the loss of human capital and the impoverishment of services and local infrastructures.

This problem is fundamental because on local levels, as far as development is concerned, technology plays a leading role. For example, human resources availability and qualification come from it, the social burden, the demand for services and market development opportunities too.

These factors also have important repercussions on the local society visibility, on the job market and on the all kinds of consumes and supplied services [11].

Depopulation is another problem. Young people run away from inhabitable alpine zones because they have not received the due spiritual and school preparation, suited for transmitting values.

The young people's nice-dress, trendy-model, fun-time and new-car psychosis, are not sufficient to explain this 
phenomenon [12].

Table 1.Italian tourists in accommodation establishments in the province of Cuneo by region of origin (2013)

\begin{tabular}{lllll}
\hline \multirow{2}{*}{ Region } & \multicolumn{2}{l}{ Total Accommodation Establishments } & & Average length of stay \\
\cline { 2 - 5 } & Arrivals & Attendances & Incidence of arrivals on total & 2,24 \\
\hline Abruzzo & 1.594 & 3.564 & $0,46 \%$ & 3,05 \\
Basilicata & 913 & 2.785 & $0,26 \%$ & 2,24 \\
Bolzano & 1.731 & 3.879 & $0,50 \%$ & 2,52 \\
Calabria & 2.916 & 7.355 & $0,84 \%$ & 2,52 \\
Campania & 5.387 & 13.550 & $1,55 \%$ & 2,17 \\
Emilia Romagna & 18.642 & 40.542 & $5,37 \%$ & 2,20 \\
Friuli Venezia Giulia & 3.502 & 7.705 & $1,01 \%$ & 2,54 \\
Lazio & 11.587 & 29.482 & $3,33 \%$ & 3,64 \\
Liguria & 58.305 & 212.129 & $16,78 \%$ & 2,03 \\
Lombardia & 65.515 & 132.889 & $18,86 \%$ & 2,18 \\
Marche & 2.589 & 5.640 & $0,75 \%$ & 2,31 \\
Molise & 691 & 1.593 & 3,47 \\
Piemonte & 128.374 & 445.525 & $0,20 \%$ & 2,93 \\
Puglia & 3.669 & 10.744 & $36,95 \%$ & 3,10 \\
Sardegna & 2.420 & 7.491 & $1,06 \%$ & 3,52 \\
Sicilia & 4.919 & 17.308 & $0,70 \%$ & 2,11 \\
Toscana & 10.922 & 22.999 & $1,42 \%$ & 1,81 \\
Trento & 2.857 & 5.185 & $3,14 \%$ & 2,06 \\
Umbria & 2.347 & 4.835 & $0,82 \%$ & 2,20 \\
Valle d'Aosta & 2.122 & 4.671 & $0,68 \%$ & 2,15 \\
Veneto & 16.462 & 35.410 & $0,61 \%$ & 2,92 \\
TOTAL & 347.464 & 1.015 .281 & $4,74 \%$ & $100,00 \%$ \\
\hline
\end{tabular}

Source: Camera di Commercio di Cuneo (2014)

It reminds us of another great person from Cuneo, an alpine passionate, Gianromolo Bignami, and of the Alpine Switzerland's young men and women who share these very same wishes and satisfy them while continuing to live in alpine centers, facing life with an aware sense of responsibility. They received a different preparation. Their State gave them what was due to them by law, no need to beg for that, and they never lost faith in the future.

In this respect IRES states (La montagna del Piemonte. Varietà e tipologie dei sistemi territoriali locali, a study): "Generally speaking, marginality is described as a cumulative process, that goes through sequential phases of demographic and economic continuation, loss of Human capital and impoverishment of the area. This is especially true for small and isolated municipalities. Demographic decrease causes the weakening of the population structure and causes a series of negative feedbacks: local residents escape, the weakening of the productive area, the collapse of local services system.

These effects generate, in return, further pushes on depopulation, creating a "perverse spiral" and a structural obstacle to the revitalization of the area. With no corrective actions, this marginality spiral forces territories towards their decline. The demographic problem, in particular, continues to be mentioned among the main causes of alpine areas critical situations, but with a decreasing importance or with, at least, different evaluation from the past. No doubt the exodus, that has long impoverished local human resources has deeply compromised this demographic structure which is very unbalanced: many more elderlies than active or qualified young people" [13] (tab.2).

Table 2. Number of foreign tourist by Province and area of destinations (in thousands)

\begin{tabular}{llllll}
\hline $\begin{array}{l}\text { Provinces and } \\
\text { Regions }\end{array}$ & $\mathbf{2 0 0 9}$ & $\mathbf{2 0 1 0}$ & $\mathbf{2 0 1 1}$ & $\mathbf{2 0 1 2}$ & $\mathbf{2 0 1 3}$ \\
\hline Torino & 1.674 & 1.722 & 1.821 & 1.968 & 2.048 \\
Vercelli & 43 & 74 & 50 & 77 & 90 \\
Novara & 163 & 190 & 201 & 254 & 235 \\
Cuneo & 257 & 341 & 352 & 353 & 284 \\
Asti & 106 & 109 & 106 & 108 & 115 \\
Alessandria & 163 & 241 & 144 & 236 & 265 \\
Biella & 76 & 83 & 66 & 75 & 70 \\
Verbano-Cusio-Osso & 457 & 694 & 523 & 799 & 876 \\
PIEMONTE & 2.940 & 3.455 & 3.263 & 3.871 & 3.983 \\
NORD-WEST & 28.634 & 29.852 & 31.659 & 32.114 & 32.844 \\
NORD-EAST & 28.872 & 29.483 & 29.670 & 31.180 & 31.188 \\
Center & 18.088 & 18.506 & 20.179 & 20.014 & 21.236 \\
South and Isles & 7.187 & 6.817 & 7.130 & 7.209 & 7.752 \\
Other & 6.613 & 6.129 & 6.958 & 7.084 & 7.089 \\
Italy & 89.395 & 90.788 & 95.596 & 97.602 & 100.110 \\
\hline
\end{tabular}

Source: Camera di Commercio di Cuneo (2014)

\section{Results and Discussion}

In conclusion, the situation of pulverized residentiality that especially hits alpine areas, generating huge socio-economic problems is a worrisome aspect.

What should we do then to help alpine mountains of Piedmont to successfully face the present challenges?

The answer is easy:

One should not consider it apart. One should insert it in the 
larger game of the European economic integration.

We will need to clarify that in the alpine area there is no school problem, no health problem, no agricultural problem, and no fiscal problem. There is a "mountain problem" made up of all these aspects. Alpine economy rests on the pillars of a polyhedral and delicate system. This is what Regione Piemonte is doing, creating the Fondo regionale per la Montagna and all the Euromed initiatives. UNCEM also often pressures for this reason, at various levels, to sustain the economic development of the area. In Piedmont, alpine municipalities (515 town halls mainly - 96\%, in the Verbano Cusio Ossola area, vs. 59\% in Provincia di Cuneo) account for a considerable quota of this area, a very large population and many resources. Many of these municipalities have demonstrated huge rally abilities.

Let's think about the XX Winter Olympic Games, which confirmed the principle that problems in many alpine areas can be faced and solved transforming them in opportunities to re-launch and develop regional economy.

Today, we should consider that local alpine systems are pictured in literature and praxis as strategic areas on which to count to create an innovative and sustainable development considering differentiation and integration among local territorial systems.

Our mountains must then be safeguarded as a whole and valorised in their different aspects, as centres of biological e cultural diversity.

\section{Conclusions}

In conclusion, what can an economist suggest in this respect? One could state: be local in a global context and innovate through what is presently existing. Give a look beyond horizontal and local limits and develop connecting nets or attraction poles on a qualitative basis.

In order to safeguard the mature area development, it seems necessary to move following five fundamental directions:

1. to identify production systems with a strategic value on which to concentrate an explicit local policy of development;

2. to grant support functions that the area has towards many variables (production, mobility, etc.) and to intervene on the relevant process of territorialisation, through articulated programs;

3. to create synergies augmenting the competition of the system;

4. to identify a small number of local homogeneous systems as areas of development and attraction;

5. to promulgate regional and trans-regional groupings able to emphasize and valorise local specificities.

Two main streams of thought dominate doctrine, with little influence though on political praxis: cohesion and rich development.

For the alpine area of Piedmont, these two concepts bring about, a totally diverse orientation from the traditional one used until now.

It is fundamental to promote:
1. territorial quality (areas where we live and work, wealth, services, knowledge, motivation);

2. territorial efficacy, in terms of development of natural resources, landscape, energy, attractiveness and competition;

3. territorial identity, safeguarding specificities and productive vocations, reinforcing competitive advantage.

Alpine mountains still have a say, what's more this say is of the utmost importance for Piedmont and for its populations. Much will depend on how our State and Region will interpret development instances, such as the construction or the amelioration of train rails, highways, alpine galleries, the effort of new and renovated industrial businesses, the sacrifice of farmers and the hard work of operators of different economic categories and local departments in charge of the management of an area.

This challenge is fascinating and gives us hope, but one must face it as a leading character and not as a passive actor.

\section{References}

[1] S. Arzeni, "Tourism a driver for growthand employment", Il Turismo, Fattore Economico di Sviluppo Locale, No. 1, 2012.

[2] A. Murdoch, "Synergies between tourism and the wider social economy: an underexplored territory?", Il Turismo, Fattore Economico di Sviluppo Locale, No. 1, 2012.

[3] J. Ejarque, "Competitività e attrattività turistica nel Mezzogiorno italiano, una prospettiva in ottica di mercato", Il Turismo, Fattore Economico di Sviluppo Locale, No. 1, 2012.

[4] W. Batging, Le Alpi. Torino: Bollati Boringhieri, 2005.

[5] M.G. Caroli, Il Marketing Territoriale. Strategie per la competitività sostenibile del territorio. Milano: Franco Angeli, 2006.

[6] S. Conti, "La città nel contemporaneo scenario competitivo", in Conti S. (a cura di), Torino nella competizione europea. Torino: Rosemberg e Sellier, 2002.

[7] V. Della Corte, La gestione dei sistemi locali di offerta turistica. Padova: Cedam, 2000.

[8] M. Franch, U. Martini, M.S. Barbera, and G. Parisi, "Lo sviluppo dell'eco-turismo come opportunità di riposizionamento strategico e di innovazione dell'offerta: uno studio di caso in una destinazione turistica matura", Proceedings of the 6th International Conference Marketing Trends, University of Cà Foscari - ESCP-EAP, Paris, 26th-27th January, 2007.

[9] R. Garibaldi, Economia e gestione delle imprese turistiche. Milano: Hoepli, 2008.

[10] A. Macchiavelli, Il Turismo montano tra continuità e cambiamento, Milano: Franco Angeli, 2006.

[11] G. Tardivo, and M. Viassone, "The measure of Financial Crisis Negative Impact on a regional context: the Piedmont case study", paper discussed at the 1er colloque international Atlas/ AFMI Association francophone de management international, les defies du Management International a l'aube du XXIe Siecle, Paris, $26^{\text {th }}-27^{\text {th }}$ May, 2011. 
[12] A. Zucchella, and S. Denicolai, Analisi strategico-organizzativa per lo sviluppo locale. Milano: Franco Angeli, 2006.
[13] IRES, La montagna del Piemonte. Varietà e tipologie dei sistemi territoriali locali. Torino: IRES, 2010. 